\title{
Bioedusiana
}

\section{PENGARUH PENGGUNAAN LEMBAR KERJA PESERTA DIDIK (LKPD) BERBASIS PROYEK TERHADAP HASIL BELAJAR PESERTA DIDIK PADA KONSEP PEMANASAN GLOBAL}

(Studi Eksperimen di Kelas VII SMP Negeri 6 Kota Tasikmalaya Tahun Ajaran 2017/2018)

The Influence of Project Based-Student Worksheet on Student's Learning Outcomes in The Global Warming Concept

\author{
Heldi Aristiadi ${ }^{1}$, Rinaldi Rizal Putra ${ }^{2}$
}

1) SMPN 3 Cipatujah, J1. Raya Ciheras No. 1 Cipatujah Kabupaten Tasikmalaya 46189 Jawa Barat 2) Jurusan Pendidikan Biologi FKIP Universitas Siliwangi, Jalan Siliwangi No. 24 Kota Tasikmalaya 46115 Jawa Barat Email korespondensi: aristiadi06@gmail.com

\section{Info Artikel}

Keywords: Student worksheet, students' learning outcomes, global warming

\begin{abstract}
Abstrak
Penelitian ini bertujuan untuk mengetahui pengaruh penggunaan lembar kerja peserta didik (LKPD) berbasis proyek terhadap hasil belajar peserta didik pada konsep pemanasan global di Kelas VII SMP Negeri 6 Kota Tasikmalaya Tahun Ajaran 2017/2018. Penelitian ini dilaksanakan pada bulan Oktober 2017 sampai dengan bulan April 2018 di SMP Negeri 6 Kota Tasikmalaya. Metode penelitian yang digunakan adalah metode true eksperiment dengan populasi seluruh kelas VII SMP Negeri 6 Kota Tasikmalaya, sebanyak 10 kelas dengan jumlah siswa 320 orang. Sampel yang digunakan sebanyak dua kelas yang diambil secara cluster random sampling yaitu kelas VII-D yang dijadikan kelas kontrol dan kelas VII-E yang dijadikan sebagai kelas eksperimen. Instrumen penelitian berupa tes hasil belajar berjumlah 38 butir soal yang berbentuk pilihan ganda dengan empat option. Teknik analisis data yang digunakan adalah uji t dan uji t deskriptif dengan taraf signifikan $(\alpha)=$ $5 \%$.Berdasarkan hasil penelitian, pengolahan, dan analisis data, menunjukan terdapat pengaruh penggunaan lembar kerja peserta didik (LKPD) berbasis proyek terhadap hasil belajar peserta didik pada konsep pemanasan global di Kelas VII SMP Negeri 6 Kota Tasikmalaya Tahun Ajaran 2017/2018.
\end{abstract}

\begin{abstract}
This study aimed to determine the influence of project based learning (PjBL) student worksheet to the learning outcomes of Junior High School students on the concept of Global Warming on the VII grade of SMP Negeri 6 Kota Tasikmalaya academic year 2017/2018. This research was conducted in October 2017 until April 2018 in SMP Negeri 6 Kota Tasikmalaya. This research used True Experiments method, with the population in this study is all students of class VII SMP Negeri 6 Kota Tasikmalaya as many as 320 people which is divided into ten classes. The sample used is two classes taken by cluster random sampling technique that is class VII D as the control class and class VII E as the experiment class. Research instrument in the form of test result of study amounted to 38 item of question which in the form of multiple choice with four option. Data analysis technique used is $t$ test and descriptive $t$ test with significant level $(\alpha)=5 \%$. Based on the results of research, data analysis and hypothesis testing obtained conclusion that there are influence of project based learning (PjBL) student worksheet to the learning outcomes of Junior High School students in the topic of global warming on the VII grade of SMP Negeri 6 Kota Tasikmalaya academic year 2017/2018.
\end{abstract}

(C) 2018 Universitas Siliwangi ISSN 2477-5193

\footnotetext{
Jurusan Pendidikan Biologi FKIP Universitas Siliwangi

Gedung Perkantoran FKIP Lt. 3

Jalan Siliwangi No. 24 Kota Tasikmalaya 46115

HP. 081235955555 (a.n. Romy Faisal Mustofa, M.Pd.)

E-mail: syahla.aini@gmail.com
} 


\section{PENDAHULUAN}

Kemajuan teknologi informasi dan komunikasi yang terjadi saat ini merupakan dampak dari kemajuan pendidikan yang semakin pesat. Kemajuan Pendidikan salah satu aspek penting yang diperhatikan dan diprioritaskan oleh Indonesia, karena dengan adanya pendidikan yang memadai dan terdistribusi secara merata, tujuan pendidikan nasional yang tercantum pada UUD 1945 alinea keempat tentang usaha untuk mencerdaskan kehidupan bangsa dapat tercapai. Tujuan pendidikan ini dapat dicapai dengan adanya tiga elemen pendidikan, yaitu pendidikan sains, pendidikan sosial dan pendidikan agama.

Pendidikan sains pada sekolah menengah pertama disebut dengan IPA terpadu. IPA merupakan bidang studi yang dalam pembelajarannya menggabungkan berbagai bidang ilmu pengetahuan (fisika, kimia dan biologi) sebagai dasar untuk memecahkan masalah yang timbul dipandang secara terintegrasi. Hakikatnya, Ilmu Pengetahuan Alam (IPA) Terpadu dibangun atas dasar sikap ilmiah, proses ilmiah dan produk ilmiah. Menurut Admoko, Setyo (2017:38), "IPA sebagai sikap membuat seseorang mampu bekerja sama. IPA sebagai proses dapat dipahami sebagai prosedur pemecahan masalah melalui eksperimen. IPA sebagai produk diartikan sebagai hasil proses berupa pengetahuan".

Pembelajaran IPA hendaknya berorientasi pada aktivitas-aktivitas yang mendukung terjadinya pemahaman konsep, prinsip, dan prosedur dalam kaitannya dengan konteks kehidupan mereka sehari-hari di dalam sekolah maupun luar sekolah. Dengan demikian pembelajaran IPA menjadi lebih menarik dan menyenangkan serta terciptanya pembelajaran yang aktif dan efektif.Untuk menciptakan pembelajaran IPA yang demikian, maka perlu dilakukan inovasi dalam hal startegi, pendekatan, dan bahan belajar. Dalam penelitian ini, inovasi yang akan dilakukan dalam rangka membuat pembelajaran IPA lebih menarik dan menyenangkan adalah dengan bahan belajar berupa Lembar Kerja Peserta Didik (LKPD).

Permasalahan yang terjadi dilapangan, guru kurang memahami mengenai fungsi LKPD sebagai bahan ajar dan menganggap bahwa
LKPD hanya sebagai rangkuman materi dan pertanyaan-pertanyaan saja. Sehingga dalam proses pembelajaran, guru biasanya menggunakan buku paket dan LKPD yang disediakan disekolah. LKPD yang digunakan tidak dibuat oleh guru sendiri. LKPD yang digunakan kurang dimanfaatkan dalam kegiatan belajar. LKPD seringkali dikerjakan dirumah atau sebagai pekerjaan rumah sehingga kurang memacu siswa untuk lebih aktif dalam kegiatan belajar. Selain itu, permasalahan lainnya seperti LKPD yang hanya terpaku pada pertanyaanpertanyaan normatif pun menjadi masalah tersendiri dalam proses pembelajaran. Hal ini pun terjadi pada pembelajaran IPA di SMPN 6 Kota Tasikmalaya.

Berdasarkan hasil wawancara yang dilakukan oleh penulis dengan guru IPA kelas VII SMPN 6 Kota Tasikmalaya pada tanggal 1 November 2017, bahwa proses belajar mengajar belum sepenuhnya melibatkan peserta didik secara aktif dan mandiri. Siswa hanya belajar dari apa yang dijelaskan oleh guru dan hanya mengacu pada LKPD yang digunakan tanpa mencari tahu sendiri. Guru lebih mendominasi dalam aktivitas belajar mengajar dengan ceramah. Hal ini akan menyebabkan proses pembelajaran kurang melibatkan peserta didik, sehingga berakibat pada hasil belajar peserta didik yang cenderung rendah.

Hasil belajar yang cenderung rendah terjadi pada pembelajaran IPA. Masalah yang muncul adalah dilihat dari nilai rata-rata ulangan harian peserta didik pada mata pelajaran IPA semester pertama tahun ajaran 2017/2018 yakni 71,00 sedangkan Kriteria Ketuntasan Minimal (KKM) yang seharusnya mencapai nilai 75,00 belum dapat terpenuhi. Sebagian besar peserta didik diindikasikan tidak mampu menguasai konsep yang ada pada materi pembelajaran IPA, salah satunya adalah konsep Pemanasan Global. Padahal pada dasarnya, materi Pemanasan Global merupakan salah satu materi yang dalam beberapa prosesnya bersifat nyata dan kompleks, konsep-konsep yang diajarkan tidak bersifat hafalan tetapi bersifat pemahaman. Jadi seharusnya LKPD yang digunakan dapat membuat siswa memahami materi berdasarkan pengalaman dan pencarian informasi oleh dirinya sendiri. 
Melihat permasalahan tersebut, keadaan yang diharapkan adalah peserta didik mampu memahami konsep Pemanasan Global dan hasil belajar yang diperoleh dapat memenuhi atau melampai kriteria ketuntasan. Oleh karena itu, diperlukan penelitian untuk meningkatkan hasil belajar melalui penggunaan bahan ajar inovatif berupa lembar kerja peserta didik (LKPD) berbasis proyek yang tepat sesuai dengan kurikulum yang diterapkan disekolah tersebut yaitu kurikulum 2013. Bahan ajar yang akan digunakan untuk meningkatkan hasil belajar peserta didik lebih menekankan kepada proses kerjasama dalam kelompok, meningkatkan kemampuan pemecahan masalah, dan pemahaman peserta didik, agar tujuan yang ingin dicapai tidak hanya kemampuan akademik dalam pengertian penguasaan konsep saja, tetapi juga adanya berbagai sikap tersebut dalam penguasaan konsep Pemanasan Global.

Penelitian yang telah dilakukan dengan menggunakan bahan ajar berupa lembar kerja peserta didik (LKPD) berbasis proyek dapat membuat proses pembelajaran lebih menarik serta tercipatnya pembelajaran yang aktif dan mandiri sehingga dapat meningkatkan hasil belajar. Menurut Piki et.al (2016:126) "Penggunaan bahan ajar berupa lembar kerja peserta didik berbasis proyek sangat efektif dan layak digunakan sebagai bahan ajar, karena berpengaruh siginifikan terhadap aspek afektif, kognitif, dan psikomotor".

Penelitian ini bertujuan untuk mengetahui pengaruh penggunaan lembar kerja peserta didik (LKPD) berbasis proyek terhadap hasil belajar peserta didik pada konsep Pemanasan Global di kelas VII SMP Negeri 6 Kota Tasikmalaya tahun ajaran 2017/2018.

\section{METODE}

Penelitian dilaksanakan di kelas VII SMPN 6 Kota Tasikmalaya semester kedua tahun ajaran 2017/2018. Kegiatan penelitian dilaksanakan pada bulan April-Mei 2018.

Metode yang digunakan dalam penelitian ini adalah metode true experiment. Dalam penelitian yang ini, yang menjadi variabel terikat adalah hasil belajar peserta didik kelas VII SMP Negeri 6 Kota Tasikmalaya pada konsep pemanasan global, sedangkan variabel bebas dalam penelitian ini adalah bahan ajar berupa Lembar Kerja Peserta Didik (LKPD) berbasis proyek.

Populasi dalam penelitian ini adalah seluruh peserta didik kelas VII SMP Negeri 6 Kota Tasikmalaya tahun ajaran 2017/2018 sebanyak sepuluh kelas dengan jumlah peserta didik sebanyak 320 peserta didik. Populasi dianggap homogen berdasarkan pada nilai ratarata ulangan harian yang diperoleh untuk mata pelajaran IPA. Sampel dalam penelitian ini adalah siswa sebanyak dua kelas dari populasi dengan menggunakan teknik cluster random sampling.

Desain penelitian yang digunakan dalam penelitian ini adalah pre-test post-test control group. Peneliti memberikan pretest terlebih dahulu kepada peserta didik sebelum dilakukan pembelajaran dan memberikan posttest setelah pembelajaran. Dengan demikian, kemajuan dapat diketahui dengan akurat, karena peneliti dapat membandingkan sebelum diberikan pembelajaran dan sesudah dilakukan pembelajaran.

Langkah-langkah penelitian yang ditempuh dalam penelitian ini yaitu: tahap persiapan di dalamnya mencakup melakukan observasi pertama, melakukan observasi kedua, mengurus perizinan untuk melakukan penelitian. Kemudian, tahap pelaksanaan meliputi pelaksanaan pembelajaran, pretest-posttest; pengolahan data seperti pengolahan dan analisis data terhadap hasil belajar yang diperoleh dari penelitian serta membuat kesimpulan.

Teknik pengumpulan data yang digunakan dalam penelitian ini adalah teknik tes. Tes berbentuk pilihan ganda dan dilakukan dengan dua tahap, yaitu pre test dan post test dalam bentuk pilihan majemuk/multiple choice dengan empat option yang terdiri dari 38 butir soal pada materi Pemanasan Global. Tujuan dari pelaksanaan tes ini adalah untuk mendapatkan skor dari hasil belajar yang telah dilakukan, baik dari kelompok eksperimen maupun kelompok kontrol.

Instrumen yang digunakan dalam penelitian ini adalah tes hasil belajar siswa pada materi pemanasan global berupa tes bentuk pilihan ganda dengan empat alternatif pilihan. Uji validitas tiap butir soal menggunakan program Anates versi 4.0.5 for windows dengan program anates. Berdasarkan hasil analisis butir 
soal dengan menggunakan program Anates versi 4.0.5 for windows, diperoleh 38 butir soal yang memenuhi kriteria valid dan 17 butir soal yang tidak memenuhi kriteria valid. maka diperoleh reliabilitas sebesar 0,93 yang berarti bahwa tes yang diberikan mempunyai tingkat reliabilitas yang sangat tinggi.

Uji kesesuaian lembar kerja peserta didik (LKPD) digunakan untuk memperoleh data kelayakan LKPD yang ditinjau dari beberapa aspek, antara lain aspek kesesuaian tata bahasa dan tampilan (semiotik), aspek sistematika, dan uji Grafik Fry.

Teknik pengolahan dan analis data dalam penelitian ini yaitu dengan uji persyaratan analisis menggunakan Uji normalitas dengan uji Normalitas dan Uji homogenitas dengan uji Fmaksimum, kemudian dilanjutkan dengan uji hipotesis menggunakan uji $t$, sementara itu pengujian LKPD menggunakan uji Grafik Fry, uji semiotik dan uji ahli LKPD.

\section{HASIL DAN PEMBAHASAN \\ Hasil Uji Kelayakan LKPD}

Berdasarkan penilaian yang dilakukan pada LKPD dengan aspek kesesuaian tata bahasa dan tampilan diperoleh skor 34 dari total skor 36 . Skor tersebut didapatkan setelah dilakukan perbaikan pertama pada LKPD. Indikator yang dinilai pada aspek kesesuaian tata bahasa antara lain penggunaan kalimat struktur yang jelas, penggunaan struktur kalimat yang sederhana dan pendek, bahasa yang digunakan baku dan mudah dipahami, bahasan yang digunakan sesuai dengan tingkat perkembangan usia peserta didik. Kemudian, pada aspek tampilan, indikator yang dinilai antara lain kesesuaian warna, halaman sampul, kejelasan tulisan, kejelasan gambar, keseimbangan garis, bentuk, ruang, tulisan, dan gambar, menyediakan ruang yang cukup untuk menulis dengan leluasa pada LKPD, dan mempunyai identitas untuk memudahkan administrasinya. Dengan demikian, setelah dilakukan perbaikan, kesimpulan validator berdasarkan hasil penilaian tersebut adalah LKPD layak digunakan tanpa revisi.

Berikutnya, penilaian dilakukan pada aspek sistematika LKPD. Aspek yang dinilai pada sistematika ini meliputi kesesuaian materi/isi, kesesuaian dengan persyaratan didaktik, kesesuaian dengan persyaratan konstruksi, dan kesesuaian dengan persyaratan teknis. Pada penolaian awal, skor yang diperoleh berdasarkan penilaian validator adalah sebesar 47 dari total 60 , dan rata-rata masih tergolong cukup dengan kriteria kualitas sangat baik, mudah dipahami, perlu disempurnakan konteks penjelasan. Hal tersebut dikarenakan terdapat beberapa indikator yang masih kurang pada setiap aspek. Setelah dilakukan perbaikan pertama, penilaian yang diperoleh dari validator mengalami peningkatan menjadi 55 dari total 60 . Hal tersebut mengidikasikan kualitas LKPD sangat baik, mudah dipahami, dan sangat sesuai dengan konteks penjelasan. Berdasarkan rekomendasi validator, maka hasil validasi LKPD disimpulkan dapat digunakan tanpa harus dilakukan perbaikan kembali.

Kemudian, berdasarkan pengujian tingkat kesulitan atau kemudahan dalam membaca teks pada LKPD dengan menggunakan uji Fry, diperoleh hasil bahwa teks yang digunakan dalam LKPD tersebut sudah cocok untuk digunakan pada peserta didik kelas VII SMP, seperti yang terdapat pada Gambar 1.

\section{Hasil Belajar Peserta Didik Kelas Eksperimen dan Kelas Kontrol}

Berdasarkan analisis hasil uji hipotesis perbedaan hasil belajar peserta didik sebelum pembelajaran menggunakan LKPD berbasis proyek dengan sesudah menggunakan LKPD berbasis proyek dengan menggunakan uji $t$ diperoleh nilai $t_{\text {hitung }} 19,8$ maka analisis menunjukan $t_{\text {hitung }}$ berada didaerah penolakan $\mathrm{H}_{\mathrm{o}}$ artinya terdapat perbedaan yang signifikan hasil belajar peserta didik sebelum pembelajaran menggunakan LKPD berbasis proyek dengan sesudah mengunakan LKPD berbasis proyek. Hal ini dapat dilihat dari perolehan nilai rata-rata pretest sebesar 20,5 posttest sebesar 33,1 dan gain sebesar 12,96 dikelas eksperimen, sebagaimana yang terdapat pada Gambar 2.

Kemudian, berdasarkan analisis hasil uji hipotesis perbedaan hasil belajar peserta didik sebelum pembelajaran yang tidak menggunakan LKPD berbasis proyek dengan sesudah pembelajaran yang tidak menggunakan LKPD berbasis proyek dengan menggunakan uji $t$ diperoleh nilai $t_{\text {hitung }}$ 9,38 maka analisis 
menunjukan $t_{\text {hitung }}$ berada didaerah penolakan $\mathrm{H}_{\mathrm{o}}$ artinya terdapat perbedaan yang signifikan hasil belajar peserta didik sebelum pembelajaran yang tidak menggunakan LKPD berbasis proyek dengan sesudah pembelajaran yang tidak menggunakan LKPD berbasis proyek. Hal ini dapat dilihat dari perolehan nilai rata-rata pretest sebesar 16,5 posttest sebesar 25,3 dan gain sebesar 6,78 dikelas kontrol.
Adanya perbedaan tersebut karena pembelajaran yang tidak menggunakan LKPD berbasis proyek di kelas kontrol cenderung kurang menarik dan memotivasi peserta didik, hal ini disebabkan karena penyelesaian proyek yang dilakukan peserta didik tidak terstrukur dan terarah, sehingga hasil belajar yang diperoleh kurang maksimal.

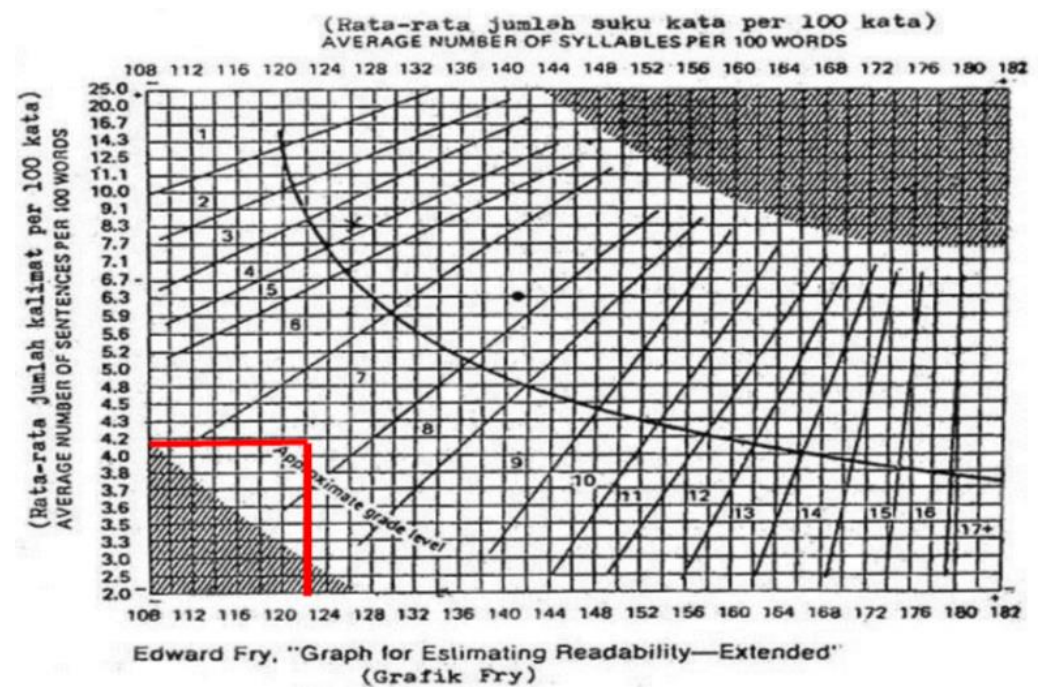

Gambar 1. Hasil pengujian sampel teks pada LKPD dengan Grafik Fry

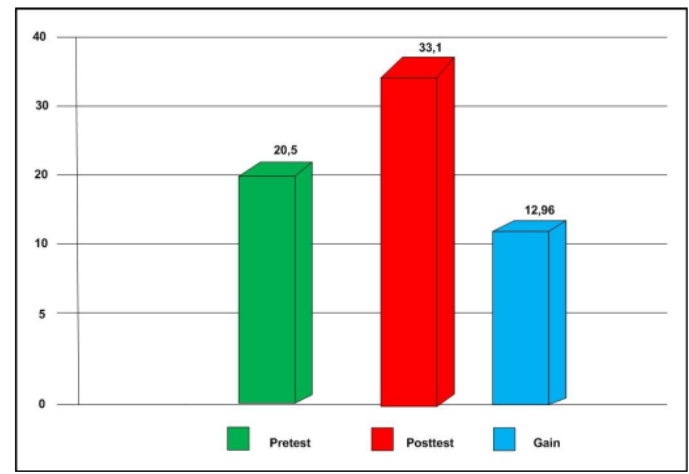

A

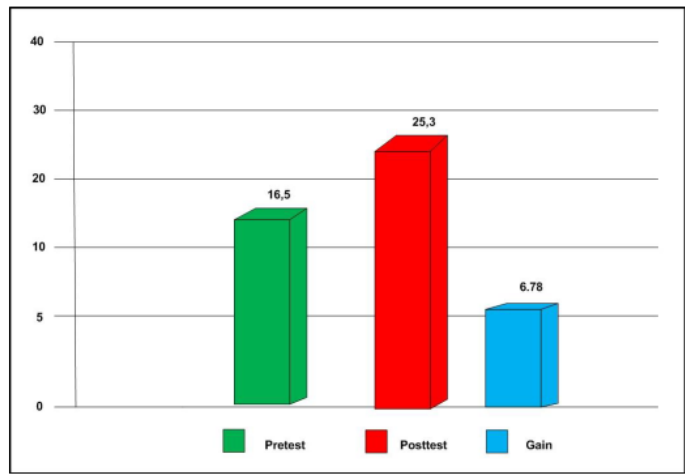

B

Gambar 2. Diagram hasil belajar peserta didik di kedua kelas: (A) Kelas eksperimen; (B) Kelas kontrol 
Hasil belajar di kelas eksperimen lebih baik dikarenakan selama proses pembelajaran, pada kelas eksperimen peserta didik terkondisikan berfikir kreatif dan mandiri yang tidak mengaharuskan mereka menjawab sesuai teori tetapi menurut logika berfikir mereka sendiri dalam menjawab pertanyaan-pertanyaan. Peserta didik diajak untuk berfikir kritis dan kreatif, berani memberi pendapat dan jawaban, dan berani menanyakan hal-hal yang tidak mengerti. Peserta didik dilatih untuk bisa bersosialisasi, menghargai perbedaan dengan sesamanya, dan bertanggung jawab didalam kelompoknya masing-masing, karena semua aktifitas ini dilakukan dalam suasana pembelajaran yang menyenangkan. Hal ini didukung oleh penelitian yang dilakukan oleh Pratiwi (2015) yang menjelaskan bahwa penerapan model PjBL berbantuan LKS pada pembelajaran IPA mampu meningkatkan hasil belajar peserta didik, baik pada aspek kognitif, afektif, maupun psikomotorik. Senada dengan Pratiwi (2015), hasil penelitian Abidin (2014) menjelaskan bahwa model PjBL adalah model yang secara langsung melibatkan peserta didik dalam kegiatan belajar melalui pengerjaan proyek suatu konsep tertentu. Dengan demikian, PjBL mampu mampu meningkatkan kemampuan dan keterampilan peserta didik karena mampu mengajak peserta didik untuk bertindak dengan cara yang alami sebagaimana otak manusia berfungsi (Ardika et. al., 2016). Oleh karena itu, LKPD yang menggunakan prinsip berbasis proyek mampu merangsang otak untuk mengonstruk pola-pola pengetahuan melalui keterkaitan dengan konteks realita kehidupan peserta didik (Komalasari, 210).

Berdasarkan hasil penelitian, proses pembelajaran yang menggunakan LKPD berbasis proyek lebih baik dibandingkan dengan yang tidak menggunakan LKPD berbasis proyek. Dengan penggunaan LKPD berbasis proyek pembelajaran peserta didik lebih efektif dan kondusif. Peningkatan hasil belajar di kelas eksperimen terjadi karena peserta didik sudah mulai menunjukan ketertarikan dan antusiasme saat mengerjakan LKPD berbasis proyek (Ardika et. al., 2016). Hasil penelitian ini didukung oleh pernyataan Ardika et. al. (2016) yang menjelaskan bahwa selain menunjukkan ketertarikan dan atusiasme, peserta didik pada kelas eksperimen yang menggunakan LKPD berbasis proyek tidak merasa kesulitan dalam membuat rancangan kerja/pembuatan proyek. Hal ini dikarenakan peserta didik telah terkondisikan mengikuti prosedur yang terdapat di dalam LKPD berbasis proyek.

Selama proses pembelajaran berlangsung, sebagian besar peserta didik menunjukan minat yang tinggi dan aktif dalam proses pembelajaran. Peserta didik tidak merasa kesulitan dalam melakukan rancangan pembuatan proyek, karena dalam hal ini peserta didik mengikuti prosedur yang terdapat di dalam LKPD berbasis proyek. Selain itu, guru juga melakukan monitoring penyelesaian proyek, sehingga peserta didik bebas melakukan eksplorasi. Berdasarkan pembahasan tersebut, dapat disimpulkan bahwa ada pengaruh penggunaan lembar kerja peserta didik (LKPD) berbasis proyek terhadap hasil belajar peserta didik pada konsep Pemanasan Global di kelas VII SMP Negeri 6 Kota Tasikmalaya.

\section{SIMPULAN, SARAN, DAN REKOMENDASI}

Berdasarkan hasil penelitian, pengolahan data, dan pengujian hipotesis, maka penulis menyimpulkan bahwa terdapat pengaruh penggunaan lembar kerja peserta didik (LKPD) berbasis proyek terhadap hasil belajar peserta didik pada konsep Pemanasan Global di Kelas VII SMP Negeri 6 Kota Tasikmalaya.

Berdasarkan hasil penelitian yang telah dilakukan, maka penulis menyarankan:

1. dalam menerapkan LKPD berbasis proyek guru hendaknya melakukan persiapan yang matang mengenai materi yang akan dijadikan proyek sebelum melakukan proses pembelajaran;

2. pelaksanaan uji coba diharapkan memiliki waktu yang tidak terganggu dengan acara atau agenda sekolah sehingga alokasi waktu yang diperlukan dapat efektif dan efisien;

3. guru hendaknya mempersiapkan visualisasi tema proyek melalui pengemasan yang menarik sehingga siswa termotivasi untuk mengerjakan proyek; dan 
4. bagi peneliti selanjutnya, hendaknya mencoba untuk lebih mengoptimalkan LKPD berbasis proyek serta membuktikan pada pokok bahasan, kelas, dan sekolah yang berbeda

\section{DAFTAR PUSTAKA}

Abidin, Yunus. (2014). Desain Sistem Pembelajaran Dalam Konteks Kurikulum 2013. Bandung: PT. Refika Aditama.

Achmad, R. (2011). Isu Lingkungan Global. Jurnal Kimia Lingkungan.1(3):1-34.

Admoko, S. (2017). Penerapan Perangkat Model Discovery Learning Pada Materi Pemanasan Global Untuk Melatihkan Kemampuan Literasi Sains Siswa SMP Kelas VII. Jurnal Sains 5(1) : 38-45. UNESA

Andi, Prastowo. (2015). Panduan Kreatif Membuat Bahan Ajar Inovatif. Yogyakarta: Diva Press

Ardika, P.R.U., \& Wahyudi, I. (2016). Pengaruh Lks Pjbl Terhadap Hasil Belajar Siswa Smp Pada Materi Suhu dan Perubahannya. Jurnal Pembelajaran Fisika, 4(3) : 115-126. Universitas Lampung.

Arikunto, Suharsimi. (2013). Prosedur Penellitian: Suatu Pendekatan Praktik. Jakarta: Rineka Cipta.

Aritonang, K.T. (2008). Minat dan Motivasi dalam Meningkatkan Hasil Belajar Siswa. Jurnal Pendidikan Penabur, 10(7): 11-21.

Arya Wardhana, Wisnu. (2010). Dampak Pemanasan Global. Yogyakarta : C.V ANDI OFFSET

Aqib, Zainal. (2013). Model-Model, Media, Dan Strategi Pembelajaran Kontekstual (Inovatif). Bandung: Yrama Widya.

Bessy, E. (2016). Peningkatan Hasil Belajar Biologi dengan Materi Pencemaran Lingkungan Melalui Penerapan Metode Berbasis Tugas Proyek Bagi Siswa kelas X Semester II SMAN 5 Kota Ternate Tahun Pelajaran 2015/2016. EDUKASI Jurnal
Pendidikan Biologi FKIP Universitas Maluku Utara (Juni, 2015). 14(2) : 482493.

Damayanti, D.S., Ngazizah, N., \& Setyadi, K.E. (2013). Pengembangan Lembar Kerja siswa (LKS) dengan Pendekatan Inkuiri Terbimbing untuk Mengoptimalkan Kemampuan Berfikir Kritis Peserta Didik pada Materi Listrik Dinamis SMA Negeri 3 Purworejo Kelas X Tahun Pelajaran 2012/2013. Jurnal Berkala Pendidikan Fisika, 3(1), 58-62.

Fitriani, F., Hasan, M.H.M., \& Musri, M. (2017). Pengembangan Lembar Kegiatan Peserta Didik (LKPD) Berbasis Masalah untuk Meningkatkan Pemahaman Konsep dan Aktivitas Belajar Peserta Didik pada Materi Larutan Penyangga. Jurnal Pendidikan Sains Indonesia, 4(1).

Himala, Sidra P. T., et.al. (2016). "Keterbacaan Teks Buku Ajar Berbasis Aktivitas pada Materi Ruang Lingkup Biologi Kelas X SMA". Jurnal Bioedu. Vol. 5 No. 3. ISSN: 2302-9528. Universitas Negeri Yogyakarta.

Katriani, Laila. (2014). Pengembangan Lembar Kerja Peserta Didik (LKPD). Makalah disampaikan dalam PPM "Pelatihan Pembuatan Perencanaan Pembelajaran IPA untuk Kegiatan Belajar Mengajar di Kelas Sebagai Implementasi Kurikulum 2013 bagi Guru, 24 Oktober, Yogyakarta.

Kemendikbud. (2013). Lampiran Permendikbud Nomor 81A Tahun 2013 Tentang Implementasi Kurikulum Pedoman Umum Pembelajaran. Jakarta: Kemendtrian Pendidikan dan Kebudayaan RI.

Komalasari, Kokom. (2010). Pembelajaran Kontekstual. Bandung: Refika Aditama.

Mahanal, S., Darmawan, E., Corebima, A.D., \& Zubaidah, S. (2014). Pengaruh Pembelajaran Project Based Learning (PjBL) pada Materi Ekosistem terhadap Sikap dan Hasil Belajar Siswa SMAN 2 Malang. BIOEDUKASI (Jurnal Pendidikan Biologi), 1(1). 
Novita, D., Darmawijoyo, D., \& Aisyah, N. (2016). Pengembangan LKS Berbasis Project Based Learning untuk Pembelajaran Materi Segitiga di Kelas VII. Jurnal Pendidikan Matematika, 10(2), 1-12.

Pratiwi, Rizky Agung. (2015). Penerapan Model Project Based Learning Berbantuan LKS untuk Meningkatkan Aktivitas dan Hasil Belajar IPA. Jurnal Paedagogi. Vol 3. No 5 .

Setyowati, R., Parmin, P., \& Widiyatmoko, A. (2013). Pengembangan Modul IPA Berkarakter Peduli Lingkungan Tema Polusi Sebagai Bahan Ajar Siswa SMK $\mathrm{N} 11$ Semarang. Unnes Science Education journal, 2(2).

Widodo, Ari, (2005). Taksonomi Tujuan Pembelajaran. Vol 6. No 2. Bandung: Universitas Pendidikan Indonesia 